\title{
Molecular Geometries and Electronic Structures of Methyl Pyropheophorbide-a and (Cationic) Tropolonyl Methyl Pyropheophorbides: DFT Calculation
}

\author{
Na-Ri Kim, Sujin Kim, Jin Dong Kim, Do Sung Huh, Young Key Shim, ${ }^{\dagger}$ and Sang Joon Choe ${ }^{\star}$ \\ Department of Chemistry, Institute of Basic Science. Inje Cniversit, Kimhae 621-749, Korea \\ E-mail: chemcsiamine ackr \\ ${ }^{\dagger}$ School of Nano Engineering. Inje Cinversit, Kimhae 621-749, USt \\ Received August 29, 2008, Accepted November 20,2008
}

\begin{abstract}
This study reports on the geometry optimizations and electronic structure calculations for methyl pyropheophorbide (MPPa), tropolonyl methyl pyropheophorbides (TMPPa, ITMPPa), and cationic tropolonyl methyl pyropheophorbides (TMPPa ${ }^{-} \mathrm{BF}_{4}$; $\mathrm{ITMPPa}^{+} \cdot \mathrm{BF}^{\circ}, \mathrm{TMPPa}^{-}$, and ITMPPa ${ }^{-}$) using Local spin Density Approximation (LSDA/ 6-3I $\mathrm{G}^{*}$ ) and the Restricted Hatree-Fock (RHF/6-3IG*) level theory. From the calculated results, we found that sulbstituted cationic tropolonyl groups have larger structural effects than those of substituted neutral tropolonyl groups. The order of structural change effects is ITMPPa ${ }^{-}>\mathrm{ITMPPa}^{-} \mathrm{BF}_{4}{ }^{-}>\mathrm{ITMPPa}$, as a result of the isopropyl group. Because it is an electron-releasing group, the substituted isopropyl group electronic effect on a 3-position tropolone increases the Highest Occupied Molecular Orbital and Lowest Unoccupied Molecular Orbital (HOMO-LUMO) energy gap. It was constituted that the larger the cationic characters of these photosensitizers, the smaller the HOMOLUMO band gaps are. The orbital energies of the cationic systems and the ions are stronger than those of a neutral sy'stem because of a strong electrostatic interaction. However, this stabilization of orbital energies are counteracted by the distortion of chlorin macrocycle, which results in a large destabilization of chlorin-based compound HOMOs and smaller destabilization of LUMOs as shown m TMPPa (ITMPPa), TMPPa ${ }^{+} \cdot \mathrm{BF}_{\downarrow}{ }_{-}^{-}\left(\mathrm{ITMPPa}^{-} \cdot \mathrm{BF}_{4}{ }^{-}\right.$), and $\mathrm{TMPPa}^{+}$ (ITMPPa ) of Figure 6 and Table 6-7. These results are in reasonable agreement with nomal-coordinate structural decomposition (NSD) results. The HOMO-LIMO gap is an important factor to consider in the development of photodynamic therapy (PDT).
\end{abstract}

Key Wonds: Tropolonyl methyl pyropheophorbides. Cationic tropolonyl methyl pyropheophorbides. Photody namic therapy (PDT), DFT

\section{Introduction}

Based on porphyrin structures, chlorin-based compound is a more attractive photosensitizer because of its strong absorbance band at $665 \mathrm{~nm}{ }^{1}$. The subsequent irradiation with visible light and in the presence of oxygen. specifically produces damaged cells that inactivate the microorganisms. ${ }^{2-3}$ Generally. gram-positive bacteria are efficiently photoinactivated by a variety of photosensitizers. whereas gram-negative bacteria are resistant to the action of negatively charged or neutral agent." Tropolones have been shown to be bacteriostatic and bactericidal for gram-positive and gram-negative bacterial species. ${ }^{4}$ Without the presence of an additional permeability agent cationic photosensitizer have been shown to photoinduce direct inactivation of gram-negative bacteria ${ }^{3,5}$ Cationic photosensitizer for porphyrin had been investigated by several researchers. ${ }^{1,6-10}$

In a recent study, the combined cllorin-based compounds of novel photosensitizer as PDT and the tropolones as antimicrobials were synthesized to see the dual function activities. ${ }^{1] \cdot 12}$ The combined compounds are tropolonyl methyl pyropheophorbides (TMPPa and ITMPPa) and methyl pyropheophorbide-substituted tropylium tetrafluroborates (TMPPa ${ }^{-} \mathrm{BF}_{4}{ }^{-}$.

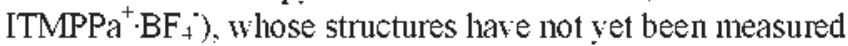
experimentally,

Density functional theory (DFT) have been extensively used to study various aspects of the porply rin macrocycle, ${ }^{\text {lita }}$ the theoretical studies on photosensitizer are relatively scare Beck's three parameter hybrid functional using the LYP correlation function (B3LYP) among the DFT is the most popular density functional theory. ${ }^{21}$ In previous study. ${ }^{15}$ the order of the maxinum difference error is HF (Hartree-Fock) > LSDA > B3LYP with respect to experimental for each model chemistry. namely, the B3LYP among the three theory is adequate. It is well-known that the HF method overestimates HOMOLUMO band gaps as compared to that of other method. ${ }^{14 k i 1}$ To calculate ligher accuracy energy models, we need to select a large basis set. It is difficult to calculate with a large basis set for these molecules. However we found that the wavelength owing to B 3LYP/6-3 IG* energy band gaps is favored with experimental value in Soret (B) and local spin density approximation (LSDA/6-31G*) energy band gaps are favored with experimental value in visible bands $(Q)$ in previous study. ${ }^{15}$ We are interested in photosensitizers to have a long wavelength from the base on calculated geometries. Thus in this study we carried out LSDA calculations because good photosensitizers may be related to the red shift of the longest wavelength $Q$ band. which enables low energy light to be used. This work is intended to serve as the basis for understanding the distortion of chlorin macrocycle by the tropolonyl group in structural effects and providing the insight of the ground state absorption (Visible band. Q band) from the calculated electronic state.

This paper presents the results of molecular geometries and electronic structures of methyl pyropheophorbide-a (MPPa). 
tropolonyl methyl pyropheophorbide-a (TMPPa). 3-isopropyltropolone methyl py ropheophorbide-a (ITMPPa). methỵl pyropheophorbide-a substituted tropylium terafluoroborate $\left(\mathrm{TMPPa}^{+} \cdot \mathrm{BF}_{4}\right)$ ), methyl pyropheophorbide-a substituted 3-isopropyl-tropylium tetrafluoroborate $\left(\mathrm{ITMPPa}^{+} \cdot \mathrm{BF}_{4}^{-}\right)$, methyl py ropheophorbide-a substituted tropylium ion (TMPPa), and methyl pyropheophorbide-a substituted 3-isopropyltropylium ion (ITMPPa ${ }^{-}$) using the LSDA/6-31G*/RHF/ 6-31G* level theory. ${ }^{16}$ Methyl pyropheophorbide-a-substituted tropylium ions (TMPPa ${ }^{-}$and ITMPPa $^{+}$) were studied to evaluate the structural consequences of electronic oxidation. On the bases of these geometries. we examine their electronic structures, particularly the Kohn-Sham eigenvalues. and the eigenstates of the four orbitals [Next Highest Occupied Molecular Orbital (NHOMO). Highest Occupied Molecular Orbital (HOMO), Lowest Unoccupied Molecular Orbital (LUMO). and Next Lowest Unoccupied Molecular Orbital (NLUMO)] in Gouterman's model.

Furthermore non-planar deformations of the chlorin macrocycle are induced by steric forces arising from the substituted tropolone and cationic tropolone in methyl py ropheophorbides. The optimized structures were later analyzed using normal-coordinate structural decomposition (NSD). ${ }^{131 \mathrm{~b} .18-19}$ As we examine the effects. the tropolonyl substitnents and the deformations of chlorins ring in $\pi$ system have been related to the visible band.

\section{Computational Methods}

DFT calculations were carried out using LSDA ${ }^{16}$ The closed-shell species (MPa. MPPa. TMPPa. ITMPPa. TMPPa ${ }^{-}$. $\mathrm{BF}_{4}$. ITMPPa ${ }^{+} \cdot \mathrm{BF}_{4}^{-}, \mathrm{TMPPa}^{+}$, and ITMPPa ${ }^{-}$were calculated with the spin-restricted method. A preliminary search for stationary structures of all studied species was carried out by geometry optimizations using the restricted Hatree-Fock (RHF) level theory. The obtained structures were for the final optimization using the LSDA level theory, then the split-valence and polarized $6-31 \mathrm{G}^{*}$ basis set were employed in the geometry optimizations. The Hartree-Fock orbital energies can be used to reproduce ultraviolet photoelectron spectra patterns via Koopman's theorem (KT). LSDA is based on densities rather than wave fiuctions and the Koln-Sham (KS) orbital energies. Wavelengths of Q band were calculated from Gouterman (the Four Orbitals). Geometries in ions (TMPPa and ITMPPa ${ }^{-}$) were also fully optimized with the $\mathrm{SCF}=\mathrm{QC}$ option to achieve convergence.

The LSDA-optimized structures are analyzed using NSD. ${ }^{1316.18-19}$ This method characterizes the chlorin conformation in terms of equivalent displacements along the normal coordinates chlorin macrocycle. Typically: the largest static distortions of the chlorin macrocycle occur along the softest normal modes. hence the greatest contributors to the nonplanar distortion are the lowest-frequency normal coordinates of each

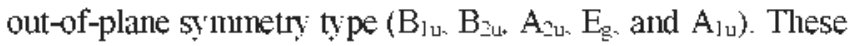
deformations correspond to the symmetric distortions commonly observed in a structure and were named ruffling (ruf), saddling (sad) doming (dom). waving (wav(xy)) and propelling (pro). ${ }^{1316.18 .19}$ They give asymme- tric macrocyclic distortions of various types. adding along the projections of the total distortions when mixed together. Only these six normal coordinates typically simulate the actual out-of-plane distortion that is reasonably accurate. The Gaussian 03 program and NSD program on Silicon Graphics Computer System were used in performing calculations and in searching for the optinum geometries using the criteria of minimum energies.

\section{Results and Discussion}

Molecular Geometries. The geometries are important because of closely relation with HOMO-LUMO band gaps and the distortion of chlorin macrocycles. Therefore we will be described to bond angles and bond lengths due to (cationic) tropolonyl groups. The structural fonmulas of methyl pyropheophorbide-a (MPPa) and metlyl pheophorbide-a (MPa) are shown in Figure 1. MPPa is obtained when the carbosyl group is decarboxylated in ring $\mathrm{V}$ in $\mathrm{MPa}$. The $\mathrm{X}$-ray crystal and molecular structure of MPa was studied by Fischer et al. (1972). ${ }^{20}$ Figure 2 shows the structural fonmula of tropolonyl methyl pyropheophorbide-a (TMPPa). 3-isopropyl-tropolone methyl pyropheophorbide-a (ITMPPa). Figure 3 shows the structural formula of cationic photosensitizers. Methyl pyropheophorbidea-substituted tropylium tetrafluoroborate $\left(\mathrm{TMPPa}^{-} \cdot \mathrm{BF}_{4}{ }^{-}\right)$and

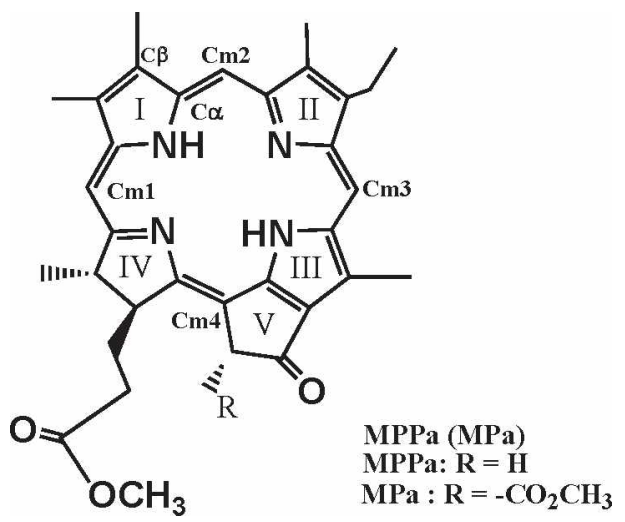

Figure 1. Structural fomula of methyl pyropheophorbide-a (MPPa) and methyl pheophorbide-a (MPa)

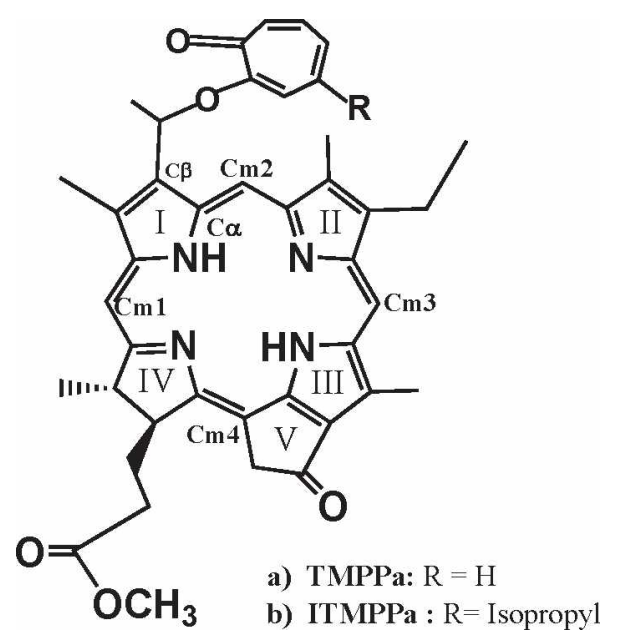

Figure 2. Structural formula of tropolonyl methyl pyropheophorbide-a (lMPPa) and 3-isopropyl-tropolone-methyl pyropheophorbide-a (l'IMPPa) 


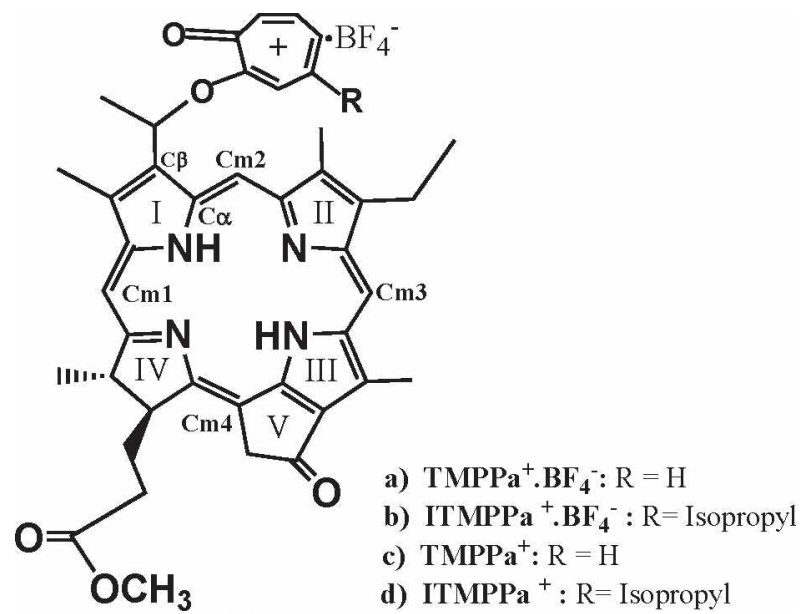

Figure 3. Structural fonmula of cationic photosensitizers: (a) methyl pyropheophorbide-a-substituted tropylium tetrafluoroborate (TMPPa$\mathrm{BF}_{4}$ ) (b) methyl py ropheophorbide-a-substituted 3 -isopropy l-tropylium terafluoroborate (ITMPPa $\cdot \mathrm{BF}_{+}^{-}$) (c) methyl pyropheophorbide-a-substituted tropylium ion ( $\mathrm{TMPPa}^{+}$)(d) methyl py ropheophorbide-a-substituted 3-isopropyl tropylinun ion (TMMPa ${ }^{7}$ )

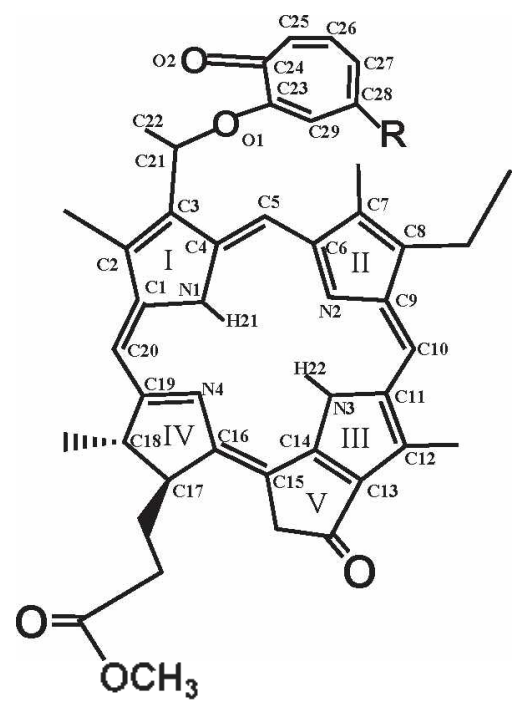

Figure 4. Selected the geometries of tropolonyl methyl pyropheophorbides-a with numerical label.

methyl py ropheo-phorbide-a-substituted 3-isopropyl-tropylium tetrafluoroborate (ITMPPa $\left.{ }^{-} \cdot \mathrm{BF}_{4}{ }^{-}\right)$were synthesized by Barkhuu. ${ }^{13}$ Methỵl pyropheophorbide-a-substituted tropylium ion (TMPPa ${ }^{-}$) and methyl pyropheophorbide-a-substituted 3-isopropyl tropylium ion (ITMPPa ${ }^{-}$) are studied to evaluate the structural consequences of electronic oxidation. TMPPa and ITMPPa were obtained when tropolone (or 3-isopropyl tropolone) was combined with MPPa. Selected LSDA-optimized bond distances in methyl (pyro) pheophorbides. tropolonyl methyl pyropheophorbides. and methyl pyropheophorbide-a-substituted tropylium ions are listed in Table 1 in accordance to the mumbering shown in Figure 4 . The calculated MPa bond lengths are good agreement with the experimental crystal structure of $\mathrm{MPa}{ }^{30}$ with a maximum difference of $-0.035 \mathrm{~A}$. Calculated bond lengths are slightly shorter than the measured ones except $\mathrm{C} 2-\mathrm{C} 3$ in ring I. 0.020-0.022 $\mathrm{A}$ for $\mathrm{Cl}-\mathrm{C} 2$ and $\mathrm{C} 3-\mathrm{C} 4$ bonds, $0.035 \mathrm{~A}$ for $\mathrm{C} 2-\mathrm{C} 3$ bond. and $0.001-0.007 \mathrm{~A}$ for $\mathrm{C} 1-\mathrm{N} 1$
Table 1. Selected Bond Distances $(A)$ of Chlorin Macrocycle in MPa. MPPa, TMPPa, ITMPPa. TMPPa ${ }^{+}$, and ITMPPa ${ }^{+}$by LSDA/6-31G*// $\mathrm{HF} / 6-31 \mathrm{G}^{*}$ Calculations

\begin{tabular}{|c|c|c|c|c|c|c|c|}
\hline & $\mathrm{MPa}$ & Exp & $\mathrm{MPPa}$ & TMPPa & ITMPPa & $\mathrm{TMPPa}^{+}$ & $\mathrm{ITMPPa}^{+}$ \\
\hline $\mathrm{Cl}-\mathrm{C} 2$ & 1.426 & 1.448 & 1.426 & 1.437 & 1.437 & 1.445 & 1.435 \\
\hline $\mathrm{C} 2-\mathrm{C} 3$ & 1.388 & 1.353 & 1.388 & 1.380 & 1.379 & 1.375 & 1.379 \\
\hline $\mathrm{C} 3-\mathrm{CH}$ & 1.439 & 1.459 & 1.439 & 1.431 & 1.432 & 1.439 & 1.432 \\
\hline $\mathrm{C} 4-\mathrm{C}_{5}$ & 1.381 & 1.371 & 1.381 & 1.383 & 1.382 & 1.387 & 1.389 \\
\hline $\mathrm{C} 5-\mathrm{C} 6$ & 1.394 & 1.412 & 1.394 & 1.395 & 1.395 & 1.390 & 1.390 \\
\hline $\mathrm{C} 6-\mathrm{C} 7$ & 1.451 & 1.429 & 1.451 & 1.451 & 1.451 & 1.457 & 1.455 \\
\hline $\mathrm{C} 7 . \mathrm{C} 8$ & 1.366 & 1.361 & 1.366 & 1.366 & 1.366 & 1.362 & 1.364 \\
\hline $\mathrm{C} 8-\mathrm{Cs}$ & 1.449 & 1.453 & 1.446 & 1.448 & 1.448 & 1.457 & 1.455 \\
\hline $\mathrm{C} 9-\mathrm{ClO}$ & 1.391 & 1.376 & 1.392 & 1.392 & 1.392 & 1.398 & 1.398 \\
\hline $\mathrm{Cl}-\mathrm{Cll}$ & 1.387 & 1.404 & 1.387 & 1.388 & 1.388 & 1.381 & 1.382 \\
\hline $\mathrm{Cl} 1-\mathrm{Cl} 2$ & 1.424 & 1.392 & 1.427 & 1.426 & 1.426 & 1.442 & 1.439 \\
\hline $\mathrm{C} 12-\mathrm{Cl} 3$ & 1.386 & 1.398 & 1.385 & 1.386 & 1.386 & 1.377 & 1.378 \\
\hline $\mathrm{Cl} 13-\mathrm{Cl} 4$ & 1.414 & 1.404 & 1.415 & 1.415 & 1.414 & 1.420 & 1.418 \\
\hline $\mathrm{Cl} 14-\mathrm{Cl} 15$ & 1.4013 & 1.388 & 1.402 & $1.4(1)$ & $1.4(1) 3$ & 1.399 & 1.400 \\
\hline $\mathrm{Cl} 5-\mathrm{Cl} 6$ & 1.387 & 1.390 & 1.383 & 1.382 & 1.382 & 1.387 & 1.386 \\
\hline $\mathrm{C} 16-\mathrm{Cl} 17$ & 1.516 & 1.492 & 1.513 & 1.513 & 1.513 & 1.505 & 1.507 \\
\hline $\mathrm{C} 17-\mathrm{C} 18$ & 1.528 & 1.551 & 1.533 & 1.534 & 1.533 & 1.534 & 1.534 \\
\hline $\mathrm{Cl} 18-\mathrm{Cl}$ & 1.506 & 1.490 & 1.508 & 1.507 & 1.507 & 1.499 & 1.501 \\
\hline $\mathrm{C} 19-\mathrm{C} 20$ & 1.385 & 1.408 & 1.386 & 1.387 & 1.388 & 1.399 & 1.395 \\
\hline $\mathrm{Cl}-\mathrm{C} 20$ & 1.390 & 1.381 & 1.390 & 1.387 & 1.387 & 1.378 & 1.382 \\
\hline CI-NI & 1.363 & 1.364 & 1.363 & 1.361 & 1.360 & 1.364 & 1.366 \\
\hline $\mathrm{C} 4-\mathrm{NI}$ & 1.365 & 1.372 & 1.365 & 1.367 & 1.367 & 1.360 & 1.363 \\
\hline $\mathrm{C} 6-\mathrm{N} 2$ & 1.354 & 1.348 & 1.354 & 1.353 & 1.353 & 1.359 & 1.359 \\
\hline $\mathrm{C}-\mathrm{N} 2$ & 1.366 & 1.373 & 1.365 & 1.366 & 1.366 & 1.360 & 1.360 \\
\hline Cll-N3 & 1.383 & 1.394 & 1.382 & 1.382 & 1.382 & 1.379 & 1.379 \\
\hline $\mathrm{Cl} 4-\mathrm{N} 3$ & 1.339 & 1.328 & 1.340 & 1.340 & 1.340 & 1.341 & 1.340 \\
\hline C. $6-\mathrm{N} 4$ & 1.355 & 1.347 & 1.354 & 1.355 & 1.355 & 1.360 & 1.359 \\
\hline CI9-N4 & 1.344 & 1.340 & 1.342 & 1.341 & 1.341 & 1.337 & 1.339 \\
\hline $\mathrm{N} 1-\mathrm{H} 2 \mathrm{l}$ & 1.029 & - & 1.029 & 1.029 & 1.029 & 1.029 & 1.029 \\
\hline $\mathrm{N} 3-\mathrm{H} 22$ & 1.041 & - & 1.043 & 1.043 & 1.043 & 1.041 & 1.041 \\
\hline
\end{tabular}

${ }^{\circ} \operatorname{Ref} 20$

and $\mathrm{C} 4 \mathrm{-Nl}$ bonds. In ring II. the difference of calculated $\mathrm{C} 8-\mathrm{C} 9$ and $\mathrm{C} 6-\mathrm{C} 7$ bonds from the measured one is 0.004 to $0.022 \mathrm{~A}, 0.005 \mathrm{~A}$ for $\mathrm{C} 7-\mathrm{C} 8$ bond. and $0.006-0.007 \mathrm{~A}$ for C6-N2 and $\mathrm{C} 9-\mathrm{N} 2$ bonds. The difference of $\mathrm{Cl} 3-\mathrm{Cl}+$ bond from the measured one is $0.010 \mathrm{~A}$ and $0.0321 \mathrm{~A}$ for $\mathrm{C} 11-\mathrm{C} 12$ bond in ring III. In ring IV, the difference of $\mathrm{Cl}-\mathrm{Cl} 7$ and $\mathrm{C} 18-\mathrm{C} 19$ bonds from measured one is $0.02+\mathrm{A}$ and $0.016 \AA$ respectively. The difference of $\mathrm{C} 12-\mathrm{C} 13$ bond in ring III and $\mathrm{Cl} 7-\mathrm{Cl} 8$ in ring IV is $0.012 \AA$ and $0.023 \AA$. respectively. In ring III. the difference of $\mathrm{C} 11-\mathrm{N} 3$ and $\mathrm{C} 14-\mathrm{N} 3$ bonds is 0.011 $\AA$ and $0.016 \AA$. respectively. In ring IV, the difference of $\mathrm{Cl}$ $\mathrm{N} 4$ and $\mathrm{C} 19-\mathrm{N}+$ bonds is $0.004 \mathrm{~A}$ and $0.008 \mathrm{~A}$. respectively. The differences of $\mathrm{C} 4-\mathrm{C} 5, \mathrm{C} 5-\mathrm{C} 6, \mathrm{C} 9-\mathrm{ClO}, \mathrm{Cl0}-\mathrm{Cl1}, \mathrm{Cl}$ $\mathrm{C} 20$, and $\mathrm{Cl}-\mathrm{C} 20$ are $0.01,0.018,0.015,0.017,0.015,0.003$. $0.023,0.009 \mathrm{~A}$, respectively.

To examine validity of bond lengths. we compared the LSDA optimized bond lengths and the HF. The LSDA optimized Mpa bond lengths are the maximum difference of $0.035 \mathrm{~A}$. whereas the HF optinuzed MPa bond lengths (see Table 9) are the maximum difference of $-0.058 \mathrm{~A}$. The LSDA optimized maximum error percentage is $2.6 \%$ and $4.3 \%$ for $\mathrm{HF}$, respectively. The average of bond length difference of the LSDA optimized Mpa is $0.01+\AA$ and $0.026 \AA$ for the HF optimized and therefore the LSDA optinized MPa bond lengths are more adequate than that of $\mathrm{HF}$

Compared to that of $\mathrm{MPPa}$. the $\mathrm{Cl}-\mathrm{C} 2$ bond lengths of 
TMPPa, ITMPPa. TMPPa ${ }^{+}$, and ITMPPa ${ }^{+}$are extended by $0.011,0.011,0.019$. and $0.009 \AA$ respectively owing to the effect on the nearest ring I by the tropolonyl and tropylium group. The $\mathrm{C} 2-\mathrm{C} 3$ and $\mathrm{C} 3-\mathrm{C} 4$ bond lengths have a maximum difference of 0.007 to $0.013 \AA$. likewise owing to the tropolonyl group and tropylium group effect on the nearest ring I. The bond lengths of TMPPa and ITMPPa have a maximum difference of 0.001 to $0.002 \AA$ in ring II-IV as compared to that of $\mathrm{MPPa}$. owing to the tropolonyl group. The bond lengths of TMPPa ${ }^{+}$and ITMPPa have a maximum difference of $0.00 \mathrm{I}$ to $0.015 \AA$ in ring II-IV as compared to that of MPPa in accordance with the tropylium group. We found that bond lengths caused by the tropylium group effect were larger than those of the tropolonyl group.

The bonds of $\mathrm{C} 4-\mathrm{C} 5, \mathrm{C} 5-\mathrm{C} 6, \mathrm{C} 9-\mathrm{C} 10, \mathrm{C} 10-\mathrm{C} 11, \mathrm{C} 19-\mathrm{C} 20$. and $\mathrm{Cl}-\mathrm{C} 20$ in TMPPa and ITMPPa are have a maxinum differences of only 0.001 to $0.003 \AA$ as compared to that of MPPa: whereas for TMPPa ${ }^{-}$and ITMPPa ${ }^{-}$, the maximum is $0.003-$ 0.013

Table 2 shows selected bond angles in methyl (pyro)pheophorbides. tropolonyl methyl pyropheophorbides, and methyl pyropheophorbide-a-substituted tropylium ions using the LSDA/ $6-31 \mathrm{G}^{*} / / \mathrm{HF} / 6-31 \mathrm{G}^{*}$ level theory. The calculated bond angles of MPa are in good agreement with the experimental crystal structure of one, ${ }^{-i}$ with a maximum difference of $\sim 2.2$ degrees. In ring $\mathrm{I}$. The $\mathrm{C} 1-\mathrm{C} 2-\mathrm{C} 3$ and $\mathrm{C} 2-\mathrm{C} 3-\mathrm{C} 4$ bond angles are increased by 0.4 and 1.6 degrees respectively, as compared to those of the measured one. In ring II-IV, the bond angles of $\mathrm{C} 6-\mathrm{C} 7-\mathrm{C} 8, \mathrm{C} 7-\mathrm{C} 8-\mathrm{C}$, $\mathrm{Cll}-\mathrm{Cl} 2-\mathrm{Cl} 3, \mathrm{Cl} 2-\mathrm{Cl} 3-\mathrm{Cl} 4 . \mathrm{Cl} 6-$ $\mathrm{C} 17-\mathrm{C} 18$, and $\mathrm{C} 17-\mathrm{C} 18-\mathrm{C} 19$ decrease except for the $\mathrm{C} 12-$

Table 2. Selected Bond Angles $\left({ }^{\circ}\right)$ of Chlorin Macrocycle in Mpa, MPPa, TMPPa, ITMPPa. TMPPa and ITMPPa by LSDA/6-31 $\mathrm{G}^{*} / / \mathrm{HF} / 6-31 \mathrm{G} *$ Calculations

\begin{tabular}{|c|c|c|c|c|c|c|c|}
\hline & $\mathrm{MPa}$ & Exp $^{a}$ & $\mathrm{MPPa}$ & TMPPa & ITMPPa & $\mathrm{TMPPa}^{-}$ & $\operatorname{ITMPPa}^{+}$ \\
\hline $\mathrm{C} 1-\mathrm{C} 2-\mathrm{C} 3$ & 107.3 & 106.9 & 107.3 & 106.1 & 106.1 & 106.2 & 106.5 \\
\hline $\mathrm{C} 2-\mathrm{C} 3-\mathrm{C} 4$ & 107.3 & 108.9 & 107.4 & 108.7 & 108.6 & 108.4 & 108.5 \\
\hline $\mathrm{C} 2-\mathrm{C} 1-\mathrm{C} 20$ & 127.0 & 126.6 & 127.1 & 126.7 & 126.6 & 125.8 & 126.5 \\
\hline $\mathrm{C} 3-\mathrm{C}_{4}-\mathrm{C}_{5}$ & 126.8 & 126.7 & 126.5 & 126.5 & 126.5 & 126.5 & 126.6 \\
\hline $\mathrm{C} 4-\mathrm{C} 5-\mathrm{C} 6$ & 128.3 & 128.8 & 128.6 & 128.6 & 128.6 & 127.9 & 128.1 \\
\hline $\mathrm{C} 5-\mathrm{C} 6-\mathrm{C} 7$ & 122.3 & 123.7 & 122.4 & 122.5 & 122.5 & 122.4 & 122.6 \\
\hline $\mathrm{C} 6-\mathrm{C} 7-\mathrm{C} 8$ & 1059 & 106.8 & 1059 & 105.9 & 105.9 & 105.8 & 105.8 \\
\hline $\mathrm{C} 7-\mathrm{C} 8-\mathrm{Cg}$ & 105.8 & 106.6 & 105.8 & 105.8 & 105.8 & 105.6 & 105.7 \\
\hline $\mathrm{C} 8-\mathrm{C} 9-\mathrm{C} 10$ & 123.8 & 125.7 & 124.0 & 124.1 & 124.1 & 123.5 & 123.6 \\
\hline C9-C10-C11 & 124.2 & 125.2 & 123.9 & 123.9 & 123.9 & 123.6 & 123.7 \\
\hline $\mathrm{C} 10-\mathrm{C} 11-\mathrm{C} 12$ & 129.9 & 131.1 & 130.3 & 130.3 & 130.4 & 129.8 & 129.9 \\
\hline $\mathrm{C} 11-\mathrm{C} 12-\mathrm{C} 13$ & 104.9 & 107.0 & 105.0 & 105.0 & 105.0 & 104.8 & 104.8 \\
\hline $\mathrm{C} 12-\mathrm{C} 13-\mathrm{C} 14$ & 109.2 & 107.0 & 109.0 & 109.0 & 109.0 & 109.2 & 109.1 \\
\hline $\mathrm{C} 13-\mathrm{Cl} 4-\mathrm{C} 15$ & 113.6 & 114.5 & 113.2 & 113.2 & 113.2 & 112.9 & 1130 \\
\hline $\mathrm{C} 14-\mathrm{Cl} 5-\mathrm{C} 16$ & 124.0 & 127.2 & 124.8 & 124.9 & 124.0 & 124.1 & 124.4 \\
\hline $\mathrm{C} 15-\mathrm{Cl} 16-\mathrm{C} 17$ & 127.7 & 126.7 & 126.6 & 126.7 & 126.7 & 126.5 & 126.6 \\
\hline $\mathrm{C} 16-\mathrm{C} 17-\mathrm{C} 18$ & 100.8 & 101.6 & 101.3 & 101.3 & 101.3 & 101.6 & 101.4 \\
\hline C17-C18-C 19 & 100.7 & 101.4 & 101.2 & 101.2 & 101.2 & 101.5 & 101.3 \\
\hline $\mathrm{C} 18-\mathrm{C} 19-\mathrm{C} 20$ & 121.8 & 123.1 & 121.9 & 122.0 & 122.0 & 121.5 & 121.7 \\
\hline $\mathrm{C} 19-\mathrm{C} 20-\mathrm{C} 1$ & 127.4 & 128.8 & 127.2 & 127.0 & 126.9 & 127.1 & 127.1 \\
\hline $\mathrm{C} 1-\mathrm{N} 1-\mathrm{C} 4$ & 110.5 & 110.5 & 110.5 & 110.2 & 110.2 & 110.0 & 110.4 \\
\hline $\mathrm{C} 6-\mathrm{N} 2-\mathrm{C} 9$ & 104.9 & 106.3 & 1050 & 105.1 & 105.1 & 104.6 & 104.7 \\
\hline $\mathrm{C} 11-\mathrm{N} 3-\mathrm{C} 14$ & 109.1 & 108.9 & 109.0 & 109.0 & 109.0 & 108.8 & 108.8 \\
\hline $\mathrm{C} 16-\mathrm{N} 4-\mathrm{C} 19$ & 108.2 & 108.2 & 108.5 & 108.5 & 108.5 & 107.9 & 108.0 \\
\hline Cl-N1-H2I & 123.6 & - & 123.1 & 123.1 & 123.1 & 124.0 & 123.4 \\
\hline C4-N1-H2l & 125.9 & - & 126.4 & 126.7 & 126.8 & 126.1 & 126.3 \\
\hline Cl1-N3-H22 & 118.6 & - & 118.2 & 118.1 & 118.1 & 118.6 & 118.6 \\
\hline $\mathrm{C} 14-\mathrm{N} 3-\mathrm{H} 22$ & 132.4 & - & 132.8 & 1.32 .9 & 132.8 & 132.6 & 1.32 .5 \\
\hline $\mathrm{N} 1-\mathrm{C} 1-\mathrm{C} 2$ & 107.8 & 107.8 & 107.8 & 108.2 & 108.3 & 108.2 & 107.8 \\
\hline $\mathrm{N} 1-\mathrm{C} 4-\mathrm{C} 3$ & 107.1 & 105.9 & 107.0 & 106.7 & 106.8 & 107.3 & 106.8 \\
\hline $\mathrm{N} 2-\mathrm{C} 6-\mathrm{C} 7$ & 111.8 & 111.4 & 111.7 & 111.7 & 111.7 & 111.9 & 111.9 \\
\hline $\mathrm{N} 2-\mathrm{Cg}-\mathrm{C} 8$ & 111.7 & 109.3 & 111.6 & 111.5 & 111.5 & 112.0 & 111.9 \\
\hline $\mathrm{N} 3-\mathrm{C} 11-\mathrm{Cl} 12$ & 108.8 & 107.8 & 108.8 & 108.8 & 108.8 & 108.9 & 108.9 \\
\hline $\mathrm{N} 3-\mathrm{C} 1+\mathrm{Cl} \hat{3}$ & 107.9 & 109.3 & 108.2 & 108.2 & 106.1 & 108.4 & 108.4 \\
\hline $\mathrm{N} 4-\mathrm{C} 16-\mathrm{Cl} 17$ & 111.1 & 112.7 & 111.7 & 111.7 & 111.6 & 112.2 & 112.1 \\
\hline N4-C $19-\mathrm{C} 18$ & 112.1 & 113.6 & 112.4 & 112.5 & 112.4 & 113.3 & 113.1 \\
\hline $\mathrm{N} 1-\mathrm{C} 1-\mathrm{C} 20$ & 125.2 & 125.2 & 125.2 & 125.1 & 125.2 & 126.0 & 125.7 \\
\hline $\mathrm{N} 1-\mathrm{C} 4-\mathrm{C} 5$ & 126.1 & 127.4 & 126.5 & 126.8 & 126.7 & 126.2 & 126.6 \\
\hline $\mathrm{N} 2-\mathrm{C} 6-\mathrm{C} 5$ & 125.9 & 124.8 & 125.9 & 125.8 & 125.8 & 125.7 & 125.5 \\
\hline $\mathrm{N} 2-\mathrm{C} 9-\mathrm{C} 10$ & 124.5 & 125.0 & 124.4 & 124.4 & 124.4 & 124.5 & 124.5 \\
\hline N3-C $11-\mathrm{C} 10$ & 121.2 & 121.1 & 120.8 & 120.8 & 125.8 & 121.4 & 121.3 \\
\hline $\mathrm{N} 3-\mathrm{C} 14-\mathrm{Cl} 5$ & 138.4 & 136.2 & 138.6 & 138.6 & 140.7 & 138.7 & 138.6 \\
\hline $\mathrm{N} 4-\mathrm{C} 16-\mathrm{C} 15$ & 121.2 & 120.5 & 121.5 & 121.5 & 121.5 & 121.1 & 121.2 \\
\hline $\mathrm{N} 4-\mathrm{C} 19-\mathrm{C} 20$ & 125.9 & 123.3 & 125.5 & 125.4 & 125.4 & 125.1 & 125.1 \\
\hline
\end{tabular}

"Ref 20 
$\mathrm{C} 13-\mathrm{Cl}+$ bond angle. as compared to those of experimental value. The optimized bond angle of $\mathrm{C} 2-\mathrm{Cl}-\mathrm{C} 20 . \mathrm{C} 3-\mathrm{C}+\mathrm{C} 5$. $\mathrm{C5}-\mathrm{C} 6-\mathrm{C} 7, \mathrm{C} 8-\mathrm{C} 9-\mathrm{C} 10 . \mathrm{Cl0}-\mathrm{C} 11-\mathrm{C} 12, \mathrm{C} 13-\mathrm{Cl} 4-\mathrm{C} 15, \mathrm{Cl} 5-$ $\mathrm{C} 16-\mathrm{C} 17$. and $\mathrm{C} 18-\mathrm{C} 19-\mathrm{C} 20$ is reduced by 0.1 to 1.4 degrees except for $\mathrm{C} 2-\mathrm{Cl}-\mathrm{C} 20$. $\mathrm{C} 3-\mathrm{C} 4-\mathrm{C} 5$ and $\mathrm{C} 15-\mathrm{Cl}-\mathrm{Cl} 7$ bond angles. The optimized LSDA bond angle of $\mathrm{C} 4-\mathrm{C5}-\mathrm{C} 6 . \mathrm{C} 9-$ $\mathrm{Cl} 0-\mathrm{Cl}, \mathrm{Cl}-\mathrm{C} 20-\mathrm{Cl}$, and $\mathrm{Cl} 4-\mathrm{Cl} 5-\mathrm{Cl} 16$ is reduced by 0.5 to 3.2 degrees. To examine validity of bond angles. we compared the LSDA optimized Mpa bond angles and the HF. The LSDA optimized Mpa bond angles are the maximum difference of $\sim$ 3.2 degree. whereas the HF optimized MPa bond angles (see Table 10 ) are the maximum difference of $\sim 4 .+$ degree. The LSDA optimized maximum error percentage is $2.5 \%$ and $3.5 \%$ for HF, respectively. The average of bond angles difference of the LSDA optimized Mpa is 1.08 degree and 1.20 degree for the HF optimized and therefore the LSDA optimized $\mathrm{MPa}$ bond angles are more adequate than that of HF.

The LSDA-optimized bond angles of MPPa have a maximum difference of $\sim 0.2$ degrees. as compared to those of $\mathrm{MPa}$ in ring l-III. In ring $\mathrm{IV}$, bond angles (C16-C17-C18. C17$\mathrm{C} 18-\mathrm{C} 19)$ are increased by 0.5 degrees as compared to those of $\mathrm{MPa}$ owing to the carboxylated group. The bond angles of $\mathrm{C} 14-\mathrm{C} 15-\mathrm{C} 16$ and $\mathrm{C} 15-\mathrm{C} 16-\mathrm{C} 17$ are increased by 0.8 and 1.1 degrees from that of $\mathrm{MPa}$. For the residue angles of $\mathrm{MPPa}$ which has a maximum difference of -0.4 degrees. The bond angles of TMPPa and ITMPPa have a maximum difference of $1.2 \sim 1.3$ degrees from MPPa in ring 1. however, the bond angles in ring II-IV were not changed. The maximum difference for the residue angles of TMPPa and ITMPPa is $\sim 0.5$ degrees. The calculated bond angles of TMPPa ${ }^{-}$and ITMPPa have a larger difference than those of TMPPa and ITMPPa. The calculated bond angles of TMPPa ${ }^{-}$and ITMPPa ${ }^{+}$are with difference of 0.8 to 1.1 degrees from MPPa in ring 1 , while the bond angles in ring II-IV have a maximum difference of $\sim 0.3$ degrees. The bond angle differences of $\mathrm{C} 2-\mathrm{Cl}-\mathrm{C} 20$ of $\mathrm{TMPPa}^{-}$and ITMPPa are 1.3 and 0.6 degrees from MPPa. respectively because of a substitute isopropy 1 group effect. The bond angle differences of $\mathrm{C} 4-\mathrm{C} 5-\mathrm{C} 6$ and $\mathrm{Cl3}-\mathrm{Cl}+\mathrm{Cl} 5$ are 0.7 degrees for TMPPa ${ }^{-}$and 0.5 and 0.4 degrees for ITMPPa, respectively.

The bond angle difference of $\mathrm{C} 10-\mathrm{C} 11-\mathrm{C} 12$ is 0.5 degrees for TMPPa and 0.4 degrees for ITMPPa. The C16-N4-C19 angle has a diference of 0.6 degrees for TMPPa ${ }^{+}$and 0.5 degrees for ITMPPa $^{+}$. Residue angles have a maximum difference of 0.5 degrees for TMPPa and 0.4 degrees for $\mathrm{TTMPP}^{+}$. Table 3 shows the selected bond distances and angles in methyl pyropheophorbide-substituted tropylium tetrafluoroborates (TMPPa ${ }^{+} \cdot \mathrm{BF}_{4}^{-}$and ITMPPa ${ }^{-} \cdot \mathrm{BF}_{4}{ }_{4}$ ). For $\mathrm{TMPPa}^{-} \cdot \mathrm{BF}_{4}$. the bond lengths of $\mathrm{Cl}-\mathrm{C} 2, \mathrm{C} 2-\mathrm{C} 3$, and $\mathrm{C} 3-\mathrm{C} 4$ have a difference of $0.008-0.01 \AA$ from $\mathrm{MPPa}$ in ring $\mathrm{I}$. The bond length of $\mathrm{C} 4-\mathrm{C} 5$ has a difference of $0.003 \AA$ in meso-2 position (m2) and $0.07 \AA$ for meso-l position (ml). In ring IV. the bond length of $\mathrm{Cl7}-\mathrm{C} 18$ has a difference of $0.002 \AA$ from MPPa. The residue distances are equal to those of $\mathrm{MPPa}$. Comparing the bond lengths of $\mathrm{TMPPa}^{+} \cdot \mathrm{BF}_{4}$ and TMPPa, they have a difference of $0.001 \mathrm{~A}$. except $\mathrm{Cl}-\mathrm{C} 2$ and $\mathrm{C} 3-\mathrm{C} 4$. The bond lengths of $\mathrm{Cl}-\mathrm{C} 2$ and $\mathrm{C} 3-\mathrm{C}+$ have a difference of $0.003 \mathrm{~A}$ and $0.002 \AA$. respectively: For ITMPPa ${ }^{+} \cdot \mathrm{BF}_{4}^{*}$, the bond lengths of $\mathrm{Cl}-\mathrm{C} 2, \mathrm{C} 2-\mathrm{C} 3$ and $\mathrm{C} 3-\mathrm{C} 4$ have a difference of $0.008-0.009 \AA$ from MPPa in ring I. Furthernore. the residue distances have a maximum difference of $0 \sim 0.003 \AA$. Comparing the bond lengths of ITMPPa ${ }^{-} \mathrm{BF}_{+}$and ITMPPa. the maximum differ-

Table 3. Selected Bond Distances $(A)$ and Angles $\left(^{\circ}\right.$ ) of Chlorin Macrocycle in $\mathrm{TMPPa}^{-} \cdot \mathrm{BF}_{4}$ and $\mathrm{ITMPPa}^{+} \cdot \mathrm{BF}_{4}$ by $\mathrm{LSDA}_{6-3} \mathrm{IG}^{*} / /$ $\mathrm{HF} / 6-31 \mathrm{G}^{*}$ Calculations

\begin{tabular}{|c|c|c|}
\hline & $\mathrm{TMPPa}^{-} \cdot \mathrm{BF}_{i}$ & $\operatorname{ITMPPa}^{+} \cdot \mathrm{BF}_{4}$ \\
\hline $\mathrm{Cl}-\mathrm{C2}$ & 1.434 & 1.435 \\
\hline $\mathrm{C} 2-\mathrm{C} 3$ & 1.380 & 1.380 \\
\hline $\mathrm{C} 3-\mathrm{C} 4$ & 1.429 & 1.430 \\
\hline $\mathrm{C} 4-\mathrm{C} 5$ & 1.384 & 1.383 \\
\hline $\mathrm{C} 5-\mathrm{C} 6$ & 1.394 & 1.394 \\
\hline $\mathrm{C} 6-\mathrm{C} 7$ & 1.451 & 1.451 \\
\hline $\mathrm{C} 7-\mathrm{C} 8$ & 1.366 & 1.366 \\
\hline $\mathrm{C} 8-\mathrm{C} 9$ & 1.448 & 1.449 \\
\hline $\mathrm{C9}-\mathrm{ClO}$ & 1.392 & 1.393 \\
\hline CIO-CII & 1.387 & 1.388 \\
\hline $\mathrm{Cl} 1-\mathrm{C} 12$ & 1.427 & 1.427 \\
\hline $\mathrm{C} 12-\mathrm{Cl} 3$ & 1.385 & 1.385 \\
\hline Cl3-C'l4 & 1.415 & 1.415 \\
\hline $\mathrm{Cl}+\mathrm{C} 15$ & 1.402 & 1.402 \\
\hline $\mathrm{Cl} 15-\mathrm{C} 16$ & 1.383 & 1.383 \\
\hline $\mathrm{C} 16-\mathrm{C} 17$ & 1.513 & 1.513 \\
\hline $\mathrm{Cl} 17-\mathrm{Cl} 8$ & 1.535 & 1.534 \\
\hline C.18-C 19 & 1.507 & 1.506 \\
\hline $\mathrm{C} 19-\mathrm{C} 20$ & 1.387 & 1.387 \\
\hline $\mathrm{Cl}-\mathrm{C} 20$ & 1.397 & 1.388 \\
\hline Cl-Nl & 1.362 & 1.361 \\
\hline C4-NI & 1.367 & 1.367 \\
\hline $\mathrm{C} 6-\mathrm{N} 2$ & 1.353 & 1.353 \\
\hline $\mathrm{C} 9-\mathrm{N} 2$ & 1.365 & 1.365 \\
\hline $\mathrm{Cll}-\mathrm{N} 3$ & 1.382 & 1.382 \\
\hline Cl4-N3 & 1.340 & 1.340 \\
\hline $\mathrm{Cl} 6-\mathrm{N} 4$ & 1.354 & 1.355 \\
\hline C.19-N4 & 1.341 & 1.341 \\
\hline $\mathrm{N} 1-\mathrm{H}_{2} \mathrm{l}$ & 1.029 & 1.029 \\
\hline $\mathrm{N} 3-\mathrm{H}_{2} 2$ & 1.043 & 1.043 \\
\hline $\mathrm{Cl}-\mathrm{C} 2-\mathrm{C} 3$ & 106.2 & 106.2 \\
\hline $\mathrm{C} 2-\mathrm{C} 3-\mathrm{C} 4$ & 108.8 & 108.7 \\
\hline $\mathrm{C} 2-\mathrm{C} 1-\mathrm{C} 20$ & 126.8 & 126.7 \\
\hline $\mathrm{C} 3-\mathrm{C} 4-\mathrm{C} 5$ & 126.6 & 126.6 \\
\hline $\mathrm{C} 4-\mathrm{C} 5-\mathrm{C} 6$ & 128.7 & 128.7 \\
\hline $\mathrm{C} 5-\mathrm{C} 6-\mathrm{C} 7$ & 122.5 & 122.5 \\
\hline $\mathrm{C} 6-\mathrm{C} 7-\mathrm{C} 8$ & 105.9 & 105.9 \\
\hline $\mathrm{C} 7-\mathrm{CB}-\mathrm{CS}$ & 105.8 & 105.8 \\
\hline $\mathrm{C} 8-\mathrm{C} 9-\mathrm{C} 10$ & 124.1 & 124.1 \\
\hline C9-Clo-Cll & 123.8 & 123.8 \\
\hline $\mathrm{C} 10-\mathrm{Cl}-\mathrm{Cl} 2$ & 130.3 & 130.3 \\
\hline $\mathrm{C} 11-\mathrm{C} 12-\mathrm{C} 13$ & 1050 & 105.0 \\
\hline $\mathrm{Cl} 2-\mathrm{Cl} 3-\mathrm{Cl} 4$ & 109.0 & 1090 \\
\hline $\mathrm{Cl3}-\mathrm{Cl} 4-\mathrm{Cl} 5$ & 113.2 & 113.2 \\
\hline $\mathrm{Cl}+\mathrm{Cl} 15-\mathrm{Cl} 6$ & 124.9 & 124.9 \\
\hline CI5-C $16-C 17$ & 126.5 & 126.6 \\
\hline $\mathrm{C} 16-\mathrm{Cl} 17-\mathrm{Cl} 18$ & 101.4 & 101.3 \\
\hline C.17-C.18-C19 & 101.3 & 101.2 \\
\hline $\mathrm{C} 18-\mathrm{C} 19-\mathrm{C} 20$ & 122.0 & 122.0 \\
\hline $\mathrm{Cl} 9-\mathrm{C} 20-\mathrm{Cl}$ & 127.1 & 127.0 \\
\hline $\mathrm{Cl}-\mathrm{Nl}-\mathrm{C} 4$ & 110.4 & 110.3 \\
\hline $\mathrm{C} 6-\mathrm{N} 2-\mathrm{C} 9$ & 105.1 & 105.1 \\
\hline CII-N3-C.14 & 109.0 & 109.0 \\
\hline C.16-N4-CI9 & 108.5 & 108.5 \\
\hline Cl-N1-H2l & 123.1 & 1230 \\
\hline $\mathrm{C} 4-\mathrm{Nl}-\mathrm{H}_{2} \mathrm{l}$ & 126.6 & 126.7 \\
\hline Cl1-N3-H22 & 118.1 & 118.2 \\
\hline Cl4-N3-H22 & 132.9 & 132.5 \\
\hline
\end{tabular}


ence is $0-0.002 \mathrm{~A}$. The bond angle difference of $\mathrm{Cl}-\mathrm{C} 2-\mathrm{C} 3$ is 1.1 degrees for $\mathrm{TMPPa}^{-} \cdot \mathrm{BF}_{4}^{-}$and ITMPPa ${ }^{+} \cdot \mathrm{BF}_{4}^{-} \cdot \mathrm{C} 2-\mathrm{C} 3-\mathrm{C} 4$ bond angle is $1 .+$ degrees for TMPPa ${ }^{-} \mathrm{BF}_{+}$and 1.3 for ITMPPa ${ }^{-}$. $\mathrm{BF}_{4}$ from MPPa in ring I. The $\mathrm{C} 2-\mathrm{C} 1-\mathrm{C} 20$ bond angle difference is 0.3 degrees for $\mathrm{TMPPa}^{+} \cdot \mathrm{BF}_{4}^{-}$and 0.4 for ITMPPa ${ }^{+}$. $\mathrm{BF}_{4}$. Comparing tropolonyl methyl pyropheophorbides (TMPPa and ITMPPa) with methyl pyropheophorbide a substitute to tropylium tetrafluoroborates (TMPPa ${ }^{+} \cdot \mathrm{BF}_{4}$ and $\mathrm{ITMPPa}^{+}$. $\mathrm{BF}_{4}$ ) for residue angles. the maximum angle difference is $0 \sim 0.2$ degrees except for the angle $\mathrm{Cl}+\mathrm{Cl} 5-\mathrm{Cl} 6$ and $\mathrm{Cl}+\mathrm{N} 3-$ $\mathrm{H} 22$. The angle differences of $\mathrm{Cl}-\mathrm{C} 15-\mathrm{C} 16$ and $\mathrm{Cl}+\mathrm{-N} 3-\mathrm{H} 22$ are 0.9 degrees and 0.3 degrees. respectively:

Table + shows the distances $(A)$ between protonated nitrogens and unprotonated nitrogen in a chlorin ring of calculated

Table 4 . The distances $(A)$ between Protonated Nitrogens and between Unprotonated Nitrogens in Chlorin rings of Calculated Molecular Systems

\begin{tabular}{lcl}
\hline \multicolumn{3}{c}{$\mathrm{LSDA} / 6-31 \mathrm{G}^{*} / \mathrm{HF} / 6-31 \mathrm{G}^{*}$} \\
\hline Molecules & $\mathrm{NH}-\mathrm{NH}^{a}$ & $\mathrm{~N}-\mathrm{N}^{b}$ \\
\hline $\mathrm{MPa}$ & 4.055 & 4.148 \\
$\mathrm{MPPa}$ & 4.045 & 4.171 \\
$\mathrm{TMPPa}$ & 4.045 & 4.171 \\
ITMPPa & 4.044 & 4.170 \\
$\mathrm{TMPPa}+$ & 4.024 & 4.151 \\
ITMPPa+ & 4.032 & 4.159 \\
$\mathrm{TMPPa}^{-} \cdot \mathrm{BF}_{4}^{-}$ & 4.045 & 4.173 \\
ITMPPaBFF$_{4}-$ & 4.046 & 4.170 \\
\hline
\end{tabular}

aH-NH: The distances between protonated nitrogen in (pyro)pheophorbides nings of molecules. "N-N: The distances between unprotonated nitrogen in (pvro)pheophorbides rings molecular systems. The distances of protonated nitrogen caused by substituted tropolonyl and cationic tropolonyl are decreased from those of MPa. whereas the unprotonated nitrogen is increased. Particularly. the distances of protonated nitrogen caused by substituted cationic tropolonyl groups are 4.024 $\AA$ for TMPPa and $+.032 \AA$ for ITMPPa all other molecules are 4.044-4.046 $\AA$. The unprotonated nitrogen distances are $4.151 \AA$ for $\mathrm{TMPPa}^{-}$and $4.159 \AA$ for ITMPPa all other molecules are 4.170-4.173 $\mathrm{A}$ except for MPa.

Table 5 shows the selected structural parameters of the tropolonyl groups and the cationic tropolonyl groups in TMPPa, ITMPPa $T \mathrm{TMPPa}^{-}, \mathrm{ITMPPa}^{+}, \mathrm{TMPPa}^{+} \cdot \mathrm{BF}_{4}$, and ITMPPa ${ }^{+}$. $\mathrm{BF}_{4}$ by LSDA $/ 6-31 \mathrm{G}^{*} / / \mathrm{HF} / 6-31 \mathrm{G}^{*}$ calculations. In order to understand substituted cationic tropolonyl group effects. we compared the substituted tropolonyl groups (TMPPa. ITMPPa) and the cationic tropolonyl groups (TMPPa ${ }^{-}$. ITMPPa ${ }^{-}$. TMPPa ${ }^{-}$. $\mathrm{BF}_{4}^{-}, \mathrm{ITMPPa}^{-} \cdot \mathrm{BF}_{4}^{-}$). The dihedral angles are more or less similar in molecular systents except ITMPPa ${ }^{-}$. The $\mathrm{C} 26-\mathrm{C} 27$ bond length of ITMPPa has maximum difference of $0.078 \AA$ from that of ITMPa. Comparing TMPPa ${ }^{+}$and ITMPPa for substituted isopropyl group effects. we found that the dihedral angles of $\mathrm{C} 23-\mathrm{Ol}-\mathrm{C} 2 \mathrm{I}-\mathrm{C} 3$ and $\mathrm{C} 23-\mathrm{Ol}-\mathrm{C} 21-\mathrm{C} 22$ have large difference of 91.4 degree and 91.2 degree respectively. The bond angle of $\mathrm{C} 25-\mathrm{C} 26-\mathrm{C} 27$ has maximum difference of 32.7 degree. The order of structural effects owing to the isopropyl group is ITMPPa ${ }^{+}>\mathrm{ITMPPa}^{-} \cdot \mathrm{BF}_{4}^{-}>$ITMPPa. We further found that substituted cationic tropolony groups are with larger structural effects than the tropolonyl group. Although the dihedral angles are large change by tropolonyl group. the distortion of chlorin macrocycle is not great influence because

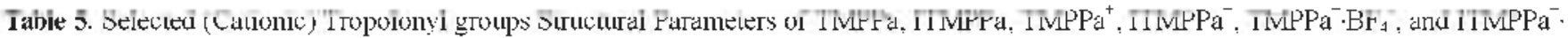
$\mathrm{BF}_{4}$ by LSDA $/ 6-31 \mathrm{G}^{*} / / \mathrm{HF} / 6-31 \mathrm{G}^{*}$ Calculations

\begin{tabular}{|c|c|c|c|c|c|c|}
\hline & TMPPa & ITMPPa & $\mathrm{TMPPa}^{-}$ & ${ }^{i} \mathrm{TMPPa}^{+}$ & $\mathrm{TMPPa}^{+} \cdot \mathrm{BF}_{+}{ }^{*}$ & $\operatorname{ITMPPa}^{-} \cdot \mathrm{BF}_{i}$ \\
\hline \multicolumn{7}{|l|}{ Dihedral angles(") } \\
\hline $\mathrm{C} 23-01-\mathrm{C} 2 \mathrm{I}-\mathrm{C} 3$ & 161.1 & 163.0 & 161.2 & 69.8 & 161.2 & 162.4 \\
\hline $\mathrm{C} 29-\mathrm{C} 23-\mathrm{Ol}-\mathrm{C} 2 \mathrm{I}$ & -1.8 & -3.1 & -2.7 & 8.1 & -1.93 & -3.0 \\
\hline $\mathrm{C} 24-\mathrm{C} 23-\mathrm{Ol}-\mathrm{C} 2 \mathrm{I}$ & 178.6 & 177.5 & 177.4 & -166.2 & 178.4 & 177.4 \\
\hline $\mathrm{O} 2-\mathrm{C} 24-\mathrm{C} 23-\mathrm{O} 1$ & -0.8 & -0.3 & -2.0 & 11.2 & -3.2 & -0.6 \\
\hline $\mathrm{C} 23-\mathrm{O} 1-\mathrm{C} 21-\mathrm{C} 22$ & -77.3 & -75.3 & -76.9 & -168.1 & -77.2 & -75.8 \\
\hline $\mathrm{C} 23-\mathrm{C} 24-\mathrm{C} 25-\mathrm{C} 26$ & 0.1 & 0.3 & 1.3 & 25.7 & 5.3 & 0 \\
\hline $\mathrm{C} 24-\mathrm{C} 25-\mathrm{C} 26-\mathrm{C} 27$ & -0.1 & -0.3 & -0.9 & -20.1 & -0.5 & -0.8 \\
\hline $\mathrm{C} 25-\mathrm{C} 26-\mathrm{C} 27-\mathrm{C} 28$ & 0.1 & -0.3 & 2.9 & -19.2 & -5.5 & 1.3 \\
\hline $\mathrm{C} 26-\mathrm{C} 27-\mathrm{C} 28-\mathrm{C} 29$ & 0.2 & 0.5 & -3.8 & 26.4 & 4.4 & -0.8 \\
\hline $\mathrm{C} 27-\mathrm{C} 28-\mathrm{C} 29-\mathrm{C} 23$ & -0.7 & 0.2 & 1.6 & -30.7 & 0.3 & 0.1 \\
\hline \multicolumn{7}{|l|}{ Bond distance $(A)$} \\
\hline C23-C24 & 1.482 & 1.481 & 1.498 & 1.501 & 1.439 & 1.486 \\
\hline $\mathrm{C} 24-\mathrm{C} 25$ & 1.439 & 1.437 & 1.441 & 1.477 & 1.443 & 1.441 \\
\hline $\mathrm{C} 25-\mathrm{C} 26$ & 1.368 & 1.368 & 1.377 & 1.309 & 1.365 & 1.346 \\
\hline $\mathrm{C} 26-\mathrm{C} 27$ & 1.409 & 1.408 & 1.363 & 1.330 & 1.388 & 1.385 \\
\hline $\mathrm{C} 27-\mathrm{C} 28$ & 1.371 & 1.375 & 1.330 & 1.425 & 1.352 & 1.375 \\
\hline \multicolumn{7}{|l|}{ Bond angle (") } \\
\hline $\mathrm{C} 23-\mathrm{C} 24-\mathrm{C} 25$ & 121.9 & 121.3 & 124.4 & 116.6 & 122.8 & 120.8 \\
\hline $\mathrm{C} 24-\mathrm{C} 25-\mathrm{C} 26$ & 132.3 & 131.8 & 130.0 & 116.3 & 131.7 & 127.6 \\
\hline $\mathrm{C} 25-\mathrm{C} 26-\mathrm{C} 27$ & 129.8 & 130.5 & 121.0 & 153.7 & 125.1 & 1390 \\
\hline $\mathrm{C} 26-\mathrm{C} 27-\mathrm{C} 28$ & 127.0 & 128.3 & 145.1 & 115.2 & 135.6 & 123.3 \\
\hline $\mathrm{C} 27-\mathrm{C} 28-\mathrm{C} 29$ & 129.5 & 126.5 & 120.8 & 121.3 & 125.3 & 126.8 \\
\hline $\mathrm{C} 28-\mathrm{C} 29-\mathrm{C} 23$ & 130.1 & 131.8 & 127.6 & 131.1 & 129.3 & 132.5 \\
\hline $\mathrm{C} 23-\mathrm{O} 1-\mathrm{C} 21$ & 122.6 & 122.4 & 122.5 & 122.9 & 122.8 & 122.6 \\
\hline
\end{tabular}


troponlonyl group is antimcrobials. The PDT activity only depends on the distortion of cllorine mcrocrcle

Tropolonyl group is added as antimicrobials to see the dual function activities of PDT. The difference of bond lengths and bond angles from the MPPa means that chlorin macrocycle on molecular systems may be influence to the distortion by the substituted stnuctural effects of tropolonyl group. although by a small amount.

\section{Electronic Stmictures}

Table 6 shows the reversed eigemalues (in eV). Gouteman's four orbitals $^{1 \%}$ [NHOMO (b2). HOMO (bl), LUMO (cl), and NLUMO (c2)] calculated by Hartree-Fock (HF). and the LSDA theory for MPa. MPPa. TMPPa and ITMPPa. The $\Delta \varepsilon_{\text {] }}$ and $\Delta \varepsilon_{\text {lul }}$ are the states associated with visible bands. ${ }^{1 "} \Delta \varepsilon_{\text {ul }}$ and $\Delta \varepsilon_{\text {mu }}$ energy gaps for MPa are $1.610 \mathrm{eV}$ and $2.256 \mathrm{eV}$, respectively: The $\Delta \varepsilon_{\mathrm{ll}}\left(\Delta \varepsilon_{\mathrm{l} y \mathrm{l}}\right)$ of MPPa. TMPPa and ITMPPa are $1.635(2.255) \mathrm{eV}, 1.671(1.933) \mathrm{eV}$, and $1.672(2.061) \mathrm{eV}$, which correspond to wavelength of $758(550) \mathrm{nm} .742(6+1)$ nim. and $7+1(601)$ nun respectively. The wavelength caused by the LSDA energy gaps show $3-12 \%$ deviations from the experimental value in $\mathrm{Q}$ bands. However owing to the tropolonyl groups, the wavelengths of TMPPa and ITMPPa are slightly blue shift as compared to that of MPPa. These tendencies are in reasonable agreement with the experimental value. ${ }^{11 \cdot 12}$ Table 7 shows the sign reversed eigenvalues (in eV). Gouterman's four orbitals. " [NHOMO(b2). HOMO(bl). LUMO(c1). and NLUMO(c2)] calculated by Hartree-Fock (HF) and LSDA theory for TMPPa ${ }^{+} \mathrm{BF}_{4}^{-}$. ITMPPa ${ }^{-} \cdot \mathrm{BF}_{4}^{-}$. $\mathrm{TMPPa}^{+}$and ITMPPa ${ }^{-} \cdot \mathrm{BF}_{4}$. The calculated $\Delta \varepsilon_{\mathrm{j}}\left(\Delta \varepsilon_{\mathrm{rrl}}\right)$ of $\mathrm{TMPPa}^{+} \cdot \mathrm{BF}_{4}^{-}$, ITMPPa ${ }^{+} \cdot \mathrm{BF}_{4}^{-}$. TMPPa ${ }^{-}$, and ITMPPa ${ }^{-}$are $1.228(1.666) \mathrm{eV} .1 .420(1.667) .0 .013(1.701) \mathrm{eV}$ and 0.072 (1.695) eV. respectively. The HOMO-LUMO band gaps $\left(\Delta \varepsilon_{\mathrm{t}}\right)$ of cationic photosensitizers $\left(\mathrm{TMPPa}^{+} \cdot \mathrm{BF}_{4}^{-}, \mathrm{TMPPa}^{-} \mathrm{BF}_{4}^{-}\right.$. TMPPa and ITMPPa ${ }^{+}$) were reduced as compared to those of TMPPa and ITMPPa, owing to tropylium tetrfluoroborates and tropylium ions. However. HOMO-LUMO band gaps have less compared to the wavelengths having the larger number. The wavelengths corresponding to the band gaps are red shift. Thus cationic photosensitizers in Table 7 are better than the neutral

Table 6. The Sign reversed eigenvalues (in $\mathrm{eV}$ ) Gouternan's four orbital [NHOMO(b2) to NLUMO(c2)] calculated using LSDA// RHF level theorv: The last two row are the HOMO-LUMO Gap $\left(\Delta \varepsilon_{\text {mul }}\right)$ and NHOMO-LUMO ( $\left.\Delta \varepsilon_{\text {hul }}\right)$. Calculated $\Delta \varepsilon_{\text {hl }}$ and $\Delta \varepsilon_{\text {hr }}$ are the state associated with visible band, parentheses are wavelengths (in nm).

\begin{tabular}{|c|c|c|c|c|}
\hline & \multicolumn{4}{|c|}{$\mathrm{LSDA} / 6-31 \mathrm{G}^{*} / / \mathrm{RHF} / 6-31 \mathrm{G}^{*}$} \\
\hline & $\mathrm{MPa}$ & $\mathrm{MPPa}$ & TMPPa & ITMPPa \\
\hline $\mathrm{b} 2$ & 5.422 & 5.281 & 5.289 & 5.277 \\
\hline bl & 5.357 & 5.228 & 5.206 & 5.191 \\
\hline $\mathrm{cl}$ & 3.747 & 3.593 & 3.535 & 3.519 \\
\hline$c 2$ & 3.101 & 2.973 & 3.273 & 3.130 \\
\hline $\begin{array}{l}\operatorname{Exp}^{\sigma} \\
\mathrm{Cal}\end{array}$ & $1.856(668)$ & $1.858(667)$ & $1.867(664)$ & $1.870(663)$ \\
\hline$\Delta \varepsilon_{\mathrm{hl}}$ & $1.610(770)$ & $1.635(758)$ & $1.671(742)$ & $1.672(741)$ \\
\hline$\Delta \oint_{\mathrm{m} m \mathrm{l}}$ & $2.256(550)$ & $2.255(550)$ & $1.933(641)$ & $2.061(601)$ \\
\hline
\end{tabular}

aref $11-12$ photosensitizers in Table 6 . because the number of band gaps is small. The isopropyl group. being the electron donor. neutralized photosensitizers. Therefore the HOMO-LUMO band gaps $\left(\Delta \varepsilon^{\prime}\right.$ L) of TMPPa, TMPPa ${ }^{+} \cdot \mathrm{BF}^{\prime}$ and TMPPa ${ }^{-}$are smaller

(a)

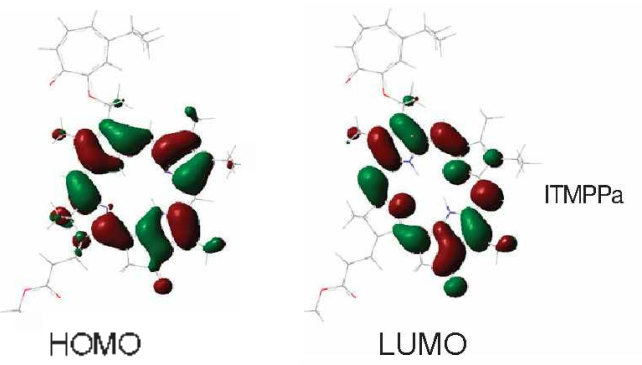

(b)

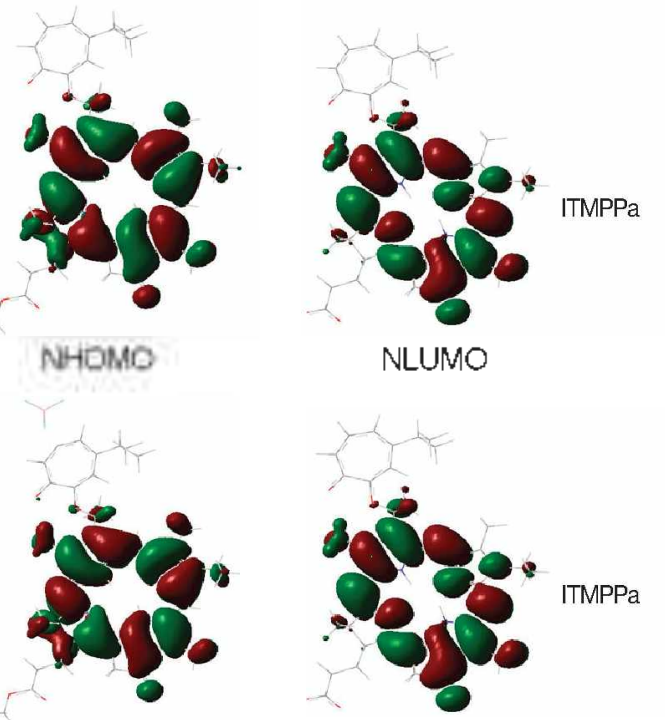

Figure 5. The molecular orbital contours of the HOMO. LUMO. NHOMO, and NLUMO for ITMPPa and ITMPPa ${ }^{-} \mathrm{BF}_{4}^{*}$, calculated from the LSDA theor: (a) HOMO and LUMO for wave function 0.02 a.u; (b) NHOMO and NLUMO for wave function 0.01 a.u.

Table 7. The Sign reversed eigenvalues (in eV) Gouterman s four orbital [NHOMO $(\mathrm{b} 2)$ to NLUMO(c2)] calculated using LSDA/RHF Calculated $\Delta \varepsilon_{\text {ju }}$ and $\Delta \varepsilon_{\text {rul }}$ are the state associated with visible band.

\begin{tabular}{ccccc}
\hline \multicolumn{4}{c}{$\mathrm{LSDA}^{-} 6-31 \mathrm{G}^{*} / \mathrm{RHF} / 6-31 \mathrm{G}^{*}$} \\
\cline { 2 - 5 } & $\mathrm{TMPPa}^{-} \cdot \mathrm{BF}_{+}^{-}$ & $\mathrm{ITMPPa}^{-} \cdot \mathrm{BF}_{4}^{-}$ & $\mathrm{TMPPa}^{-}$ & ITMPPa $^{-}$ \\
\hline $\mathrm{b} 2$ & 5.461 & 5.476 & 8.048 & 7.967 \\
$\mathrm{bl}$ & 5.387 & 5.397 & 7.934 & 7.916 \\
$\mathrm{cl}$ & 4.159 & 3.978 & 7.921 & 7.844 \\
$\mathrm{c} 2$ & 3.720 & 3.730 & 6.233 & 6.220 \\
$\mathrm{Cal}$ & & & & \\
$\Delta \varepsilon_{\text {hL }}$ & 1.228 & 1.420 & 0.013 & 0.072 \\
$\Delta \varepsilon_{\text {hrl }}$ & 1.666 & 1.667 & 1.701 & 1.695 \\
\hline
\end{tabular}


(a)

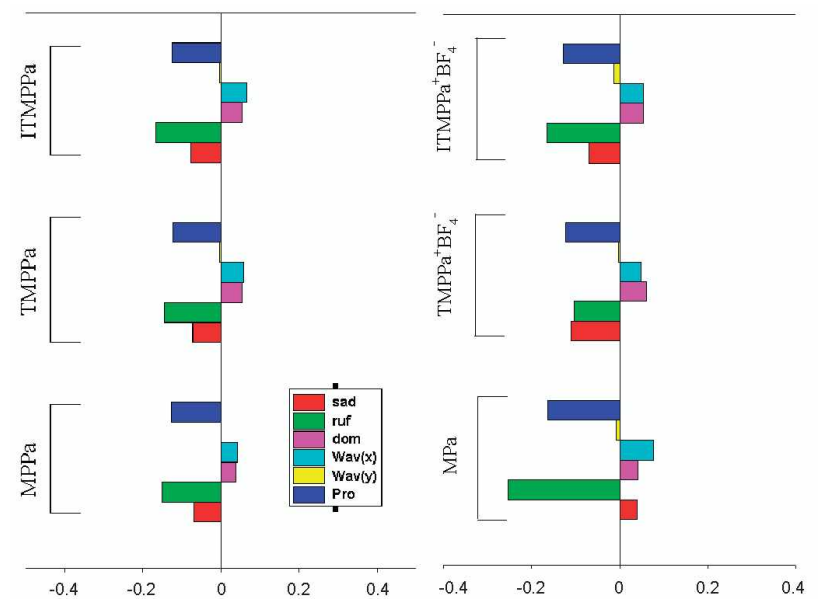

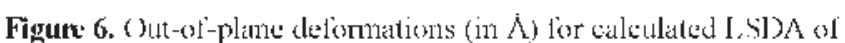
molecular st stems: (a) the deformations of MP'Pa. TMP'Pa I'l'Ml'P'a.

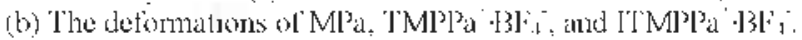

Table 8. Scleeted atonic coclicients of IIOMO and L.UMO of

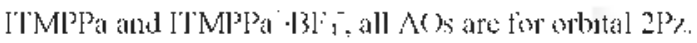

\begin{tabular}{|c|c|c|c|c|}
\hline & \multicolumn{2}{|c|}{ H I.M() } & \multicolumn{2}{|c|}{ I. UMM ) } \\
\hline & l'I'Mls $\}^{3}$ & I']'MPPa' & IlMPP'a & 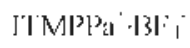 \\
\hline $\mathrm{Nl}$ & -0.049 & -0.049 & 0.000 & 0.011 \\
\hline $\mathrm{N} 2$ & -0.044 & -0.043 & 0.165 & 0.000 \\
\hline$C 3$ & 0.058 & 0.000 & 0.135 & 0.000 \\
\hline C4 & 0.190 & 0.018 & 0.148 & $-0.0(1)$ \\
\hline 65 & 0.0147 & 0.0000 & -0.156 & -0.004 \\
\hline$c 0$ & -0.191 & -0.190 & -0.093 & 0.005 \\
\hline C. 7 & -0.099 & -0.090 & 0.012 & 0.004 \\
\hline
\end{tabular}

than those of ITMPPa, ITMPPa 'BF ${ }_{4}$ and ITMPPa'. Thus the larger the cationic character of these photosentizers, the smaller the HOMO-LUMO band gaps is.

Figure 5 shows the three-dimensional (3-D) contours of the Ciouterman four orbitals with a wave-function value of 0.01 and 0,02 a.u. for ITMPPa and ITMPPa $\mathrm{BF}_{4}$ derived from the I.SDA theory: The IIOMO is delocalized on chlorin macrocycle and has not contributions from (cationic) tropolonyl groups. The LUMO is similar to the HOMO, but the LUMO orbitals on the $\mathrm{C} 17-\mathrm{C} 18$ carbon atoms in ring IV have not contributions. Table 8 lists the selected atomic coeflicients of HOMO and LUMO of ITMPPa and ITMPPa $\cdot \mathrm{BF}_{+}$. It is shown that all the signilicant atomic orbitals $2 \mathrm{P}$ \% for either $\mathrm{C}$ or $\mathrm{N}$. suggesting that HOMOs and LUMOs are $\pi$ orbitals. The atomic coefficients of HOMOs and LUMMOS in cationic photosensitizers are smaller than those of neutral photosensitizer. Nevertheless, the cigenvalues of HOMOs and LUMOs of eationic photosensitizers are larger than the neutral one because cationic systems have strong electrostatic interactions as shown in Table 7. And because of the ionic states, TMPPa and ITMPPa have a very strong electrostatic interaction.

In order to estimate the non-planar deformations of the chlorin macrocscle caused by the substituded tropolone and cationic tropolone in methyl propheophorbides. we were anta-

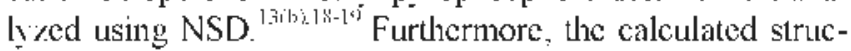
tures (MPPa. TMPPa. ITMPPa. MPa. TMPPa ${ }^{-B_{+}}$. and
Table 9. Selected bond ] istances $(\lambda)$ ol Chlorin Mactoeycle in Ml'a and Ml'Pa by HF/6-3l(i* Calculation

\begin{tabular}{|c|c|c|c|c|c|}
\hline & $\mathrm{MP}^{3} \mathrm{a}$ & Ml'l'a & & $\mathrm{Ml}^{3} \mathrm{a}$ & Ml'Pa \\
\hline $\mathrm{Cl}-\mathrm{C} 2$ & 1.477 & 1.477 & $\mathrm{C} 15-\mathrm{C} 16$ & 1.339 & 1.3 .36 \\
\hline $\mathrm{C} 2-\mathrm{C} 3$ & 1.340 & 1.340 & $\mathrm{Cl} 16-\mathrm{C} 17$ & 1.529 & 1.527 \\
\hline $\mathrm{C}^{3}-\mathrm{C}_{4}$ & 1.476 & 1.476 & C'17-C'18 & 1.543 & 1.546 \\
\hline C4-C'5 & $1.3+2$ & 1.343 & C'18-C'19 & 1.517 & 1.519 \\
\hline$(5-66$ & 1.449 & 1.449 & $C .19-(20)$ & $1.44]$ & 1.442 \\
\hline$C 6-C 7$ & 1.47 .3 & 1.472 & $\left.C^{\prime} l-C^{\prime} 20\right)$ & 1.351 & 1.350 \\
\hline$C 7-C 8$ & 1.343 & 1.344 & $\mathrm{Cl}-\mathrm{Nl}$ & 1.360 & 1.361 \\
\hline $\mathrm{C} 8-\mathrm{C})$ & 1.469 & 1.468 & $(4-N I$ & 1.373 & 1.373 \\
\hline (C) -10 & 1.347 & 1.349 & $\mathrm{C}_{6}-\mathrm{N}_{2}$ & 1.293 & 1.293 \\
\hline C.IO-C']l & 1.435 & 1.434 & $(y)-N_{2}$ & 1.394 & 1.394 \\
\hline $\left.\mathrm{C}^{\prime} 1\right]-\mathrm{C}^{\prime} \mathrm{2} 2$ & 1.381 & 1.38 .3 & CII-N3 & 1.387 & 1.385 \\
\hline $\mathrm{C} 12-\mathrm{C} 13$ & 1.418 & 1.417 & $\mathrm{C} \perp 4-\mathrm{N}^{3}$ & 1.325 & 1.326 \\
\hline $\mathrm{C} 13-\mathrm{C} 14$ & 1.375 & 1.375 & $C 16-N_{1}$ & 1.405 & 1.104 \\
\hline C $14-C) 5$ & 1.451 & 1.450 & (19-N4 & 1.283 & 1.281 \\
\hline $\mathrm{NI}-1121$ & 0.992 & 0.992 & $N 3-1122$ & 0.993 & 0.992 \\
\hline
\end{tabular}

Table 10. Selected Bond Angles(") of Chlorin Mactoeyele in MP's and Ml'Pa by IIF/6-3 I $\mathrm{j}^{*}$ Cólculation

\begin{tabular}{|c|c|c|c|c|c|}
\hline & $\mathrm{Ml}^{3} \mathrm{~d}$ & Ml'] 's & & $\mathrm{Ml}^{2} \mathrm{a}$ & MP'l'al \\
\hline $\mathrm{C}: \mathrm{I}-\mathrm{C}: 2-\mathrm{C}: 3$ & 107.9 & 107.9 & C'II-N3-C'l4 & $1(149.1$ & 109.1 \\
\hline $\mathrm{C}_{2}-\mathrm{C}_{3}-\mathrm{C}_{4}$ & 108.4 & 108.4 & $\mathrm{C} 16-\mathrm{N} 4-\mathrm{C} 19$ & 109.5 & 109.7 \\
\hline $\mathrm{C} 2 \mathrm{Cl}-\mathrm{C} 2 \mathrm{O}$ & 125.6 & 125.7 & C $1-\mathrm{N} 1-\mathrm{H} 21$ & 124.5 & 124.4 \\
\hline$C 3-C 4-C 5$ & 126.6 & 126.5 & $\mathrm{C}+4-\mathrm{N}]-\mathrm{J}+2 \mathrm{l}$ & 123.7 & 123.9 \\
\hline$C 4-C 5-C 6$ & 126.3 & 126.5 & C'l]-N3-[ [22 & 123.5 & 123.4 \\
\hline$C 5-C 6-C 7$ & 122.9 & 122.9 & C'14-N3-l[22 & 127.3 & 127.5 \\
\hline $66-6-c 8$ & 105.8 & 105.8 & $\mathrm{~N} 1-\mathrm{C} 1-\mathrm{C} 2$ & 106.3 & 106.2 \\
\hline$(7-C 8-C)$ & 106.1 & 106.1 & $\mathrm{~N} 1-\mathrm{C}-\mathrm{C}-3$ & 105.7 & 105.6 \\
\hline$(8-C)-(1) 10$ & 125.9 & 125.9 & $\mathrm{~N} 2-\mathrm{C}^{\prime} 6-\mathrm{C} \cdot 7$ & 112.5 & 112.4 \\
\hline (')-Clo-c: I & 127.5 & 127.4 & $\mathrm{~N} 2-\mathrm{C} 9-\mathrm{C} B$ & 109.3 & 109.3 \\
\hline (1)-C $11-C 12$ & 129.4 & 129.8 & $\mathrm{~N} 3-\mathrm{C} 11-\mathrm{C} 12$ & 108.7 & 1018.7 \\
\hline $\mathrm{C} 11-\mathrm{C} 12-\mathrm{C} 13$ & 1015.1 & 105.2 & $\mathrm{~N} 3-\mathrm{C}^{1} 14-\mathrm{C} 13$ & 1018.7 & 108.9 \\
\hline $\mathrm{Cl} 2-\mathrm{C} 13-\mathrm{C} 14$ & 108.3 & 108.1 & $\mathrm{~N} 4-\mathrm{C} 16-\mathrm{C} 17$ & 108.4 & 109.0 \\
\hline C $13-C \cdot 14-C \cdot 15$ & 114.5 & 114.4 & $\mathrm{~N} 4-\mathrm{C}: 19-\mathrm{C} 18$ & 113.9 & 1140 \\
\hline $\mathrm{C}^{\prime} \mathrm{l}+\mathrm{C}-15-\mathrm{C} 16$ & 124.8 & 125.2 & $\mathrm{Nl}-\mathrm{C} 1-\mathrm{C} 20$ & 128.1 & 128.1 \\
\hline $\mathrm{C} 15-\mathrm{C}) 6-\mathrm{C} 17$ & $1,31.1$ & 130.0 & $\mathrm{Nl}-\mathrm{C}+4-\mathrm{C} 5$ & 127.8 & 127.9 \\
\hline $\mathrm{C} 16-\mathrm{C} 17-\mathrm{C} 18$ & 100.9 & 101.1 & $\mathrm{~N} 2-\mathrm{C} 6-\mathrm{C} 5 \mathrm{5}$ & 124.6 & 124.7 \\
\hline$(: 17-c) 8-(: 19)$ & $100 \% 3$ & $10(10.6$ & $\mathrm{N} 2-(9)-(\cdots)$ & 124.8 & 124.8 \\
\hline $\mathrm{C} 18-\mathrm{C} 19-\mathrm{C} 20$ & 119.7 & 120.0 & N3-C11-C10 & 121.9 & 1216 \\
\hline $\mathrm{C} 19-\mathrm{C} 20-\mathrm{C} 1$ & 127.4 & 127.2 & N3-C14-C15 & 136.8 & 136.7 \\
\hline $\mathrm{CI}-\mathrm{NI}_{-} \mathrm{C}_{4}$ & 111.7 & $1] 1.7$ & N4-C']6-C'15 & 120.3 & 120.9 \\
\hline$(6)-N_{2}-(C)$ & 106.3 & 106.4 & N4-C']9-C2() & 126.4 & 1200 \\
\hline
\end{tabular}

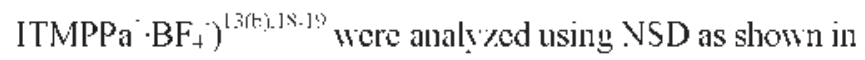
Figure 6. First comparing MPa with MPPa compound, nonplanar deformations of MPa were larger than those of MPPa. However. because of the carbovyl group effect in ring $\mathrm{V}$ of MPa as shown in Figure 1. the HOMO- LUMO band gap of MPa is a slightly smaller than that of MPPa On the other hand. NSD results show a larger change in out-of-plane deformation at T.MPPa than that of MPPa to some cxtent. From detailed NSD results of MPPa. saddling is $-0.070 \mathrm{~A}$. ruffling is -0.152 $\mathrm{A}$, doming is $0.037 \mathrm{~A}$, wav $(\mathrm{x})$ is $0.043 \mathrm{~A}$. wav(v) is $0.001 \mathrm{~A}$, and pro is $-0.127 \mathrm{~A}$. In contrast. saddling of T.MPPa is -0.073 $\mathrm{A},-0.146 \mathrm{~A}$ for ruffling, $0.054 \mathrm{~A}$ for doming, $0.058 \mathrm{~A}$ for wav (x). $-0.004 \mathrm{~A}$ wav(v). and $-0.124 \mathrm{~A}$ for pro. Hence, total observed distortion of $\mathrm{MPPa}$ is $0.218 \mathrm{~A}$, compared to that of TMPPa. which is $0.219 \mathrm{~A}$. It means that the HOMO-LUMO band gap is in reasonable agreement with the NSD results in MPPa and T.MPPa. 
Comparing TMPPa and ITMPPa. the distortion of ITMPPa is larger than that of MPPa because of the isopropyl group. which is an electron leaving group. Cationic tropolonyl groups have smaller distortions than tropolonyl groups, comparing cationic tropolonyl methyl py ropheophorbides with tropolonyl methyyl pyropheophorbides in Figure 6. The major distortions of TMPPa are $-0.073 \AA$ for saddling. $-0.1+6 \AA$ for ruffling. and $-0.124 \mathrm{~A}$ for pro. However, those of TMPPa ${ }^{+} \cdot \mathrm{BF}_{4}{ }^{4}$ are $-0.109 \mathrm{~A}$ for saddling. $-0.103 \AA$ for ruffling. and $-0.12 \mathrm{l} \AA$ for pro. Total observed distortion of $\mathrm{TMPPa}^{-} \mathrm{BF}_{4}{ }^{-}$is $0.207 \AA$. The major distortions of ITMPPa are $-0.077 \AA$ for saddling, $-0.168 \AA$ for ruffling. and $-0.126 \AA$ for pro. whereas those of ITMPPa ${ }^{-} \cdot \mathrm{BF}_{\downarrow}{ }^{-}$are $-0.069 \AA$ for saddling. $-0.165 \AA$ for ruffling. and $-0.127 \AA$ for pro.

Table 6-7 shows that the electronic effect of cationic tropolonyl groups reduces the HOMO-LUMO gap. The wavelength corresponding to the band gap increases the red shift.

\section{Conclusion}

1. We found the following results from the geometry optimization by LSDA/6-3 IG*//HF/6-31G* calculation.

a) After calculating the bond lengths and bond angles. we compared the results of $\mathrm{MPa}$ and the experimental MPa. The results are somewhat equivalent with a maximum difference of $0.000-0.035 \dot{A}$ and 0.0-3.2 degrees (see Table 1-2).

b) TMPPa and ITMPPa which were linked with tropolone change $\mathrm{C}-\mathrm{C}$ bond lengths of the nearest ring $\mathrm{I}$ by 0.007 to $0.011 \mathrm{~A}$. The $\mathrm{C} 1-\mathrm{C} 2-\mathrm{C} 3$ bond angles and $\mathrm{C} 2-\mathrm{C} 3-\mathrm{C} 4$ have a difference of 1.2 degree and 1.3 degree respectively. Other bond lengths have a maximum difference of $0.001-0.003$, and the bond angles have a maximum difference $0.5 \mathrm{de}$ grees except the $\mathrm{C} 1+-\mathrm{C} 15-\mathrm{C} 16$ bond angles of ITMPPa (Table 2).

c) $\mathrm{TMPPa}^{+}$and ITMPPa ${ }^{-}$, which were linked with tropylinm ions. changed the $\mathrm{C}-\mathrm{C}$ bond lengths of the nearest ring I by 0.000 to $0.019 \mathrm{~A}$. The $\mathrm{C} 1-\mathrm{C} 2-\mathrm{C} 3$ bond angles and $\mathrm{C} 2-\mathrm{C} 3-$ $\mathrm{C}+$ are 0.8 to 1.1 degrees. Other bond lengths have a maximum difference of $0.001-0.011 \AA$. The bond angles have a maximum difference of $\sim 1.3$ degrees (Table 2). TMPPa$\mathrm{BF}_{4}$ and ITMPPa ${ }^{+} \cdot \mathrm{BF}_{4}$, which were linked with cationic tropolone changed the $\mathrm{C}-\mathrm{C}$ bond lengths of the nearest ring I by 0.008 to $0.010 \mathrm{~A}$. The $\mathrm{C} 1-\mathrm{C} 2-\mathrm{C} 3$ bond angles and $\mathrm{C} 2-\mathrm{C} 3-\mathrm{C} 4$ have a difference of 1.1 to 1.4 degrees. Other bond lengths have a maximum difference of $0.000-0.007$ $\AA$. The bond angles have a maximum difference of $\sim 0.4$ degrees (Table 3).

2. The electronic effect of cationic tropolony 1 groups reduces the HOMO-LUMO band gap. On the other hand the isopropyl group effect increases the HOMO-LUMO band gaps.

3. The calculated energy band gaps are in reasonable agreement with the experimental value in visible bands (Q) (see Table 6)

4. The distortions of chlorin macrocycle are able to explain the normal-coordinate structural decomposition and the results are in reasonable agreement with the HOMO-LUMO energy gap.

5. The HOMO-LUMO gap is an important factor to consider in the development of PDT.

Acknowledgments. The authors whish to acknowledge financial from Ministry of Education (BK21).

\section{Refeiences}

1. Webber, J; Leeson, B.; Fromm, D; Kessel, D. J. Photochem. Photabiol 2005, 78, 135.

2. Caminos, D.; Spesia, B.: Durantini, E. Photochem. Photobiol. Sci. 2006, 5,56 .

3. DeRosa, M R: Crutchley, R J. Coont. Chent Rev 2002, 233-234, 351.

4. Trust, T. J. Antimicrob. Agents Chemother 1975, 7, 500 .

5. Nitzan, Y.; Ashkenazi, H. Cum . Hicrobiol $2001,42,408$

6. Villanueva, A. J. Phochem. Phorobiol. 1993, 18,295

7. (a) Ali, H; van Lier, E. J. Chent. Rev, 1999, 99, 2379. (b) Tasat, A.; Dolphin, D. Chent. Rev: 1997, 97, 2267.

8. Garbo, (ì. M.: Fingar, V. H.; Wieman, T. J.: Noakes III, E. B.; Haydon, P. S.; Cerrito, H. B.; Kessel, D. H.; Morgan, A. R. Photochem. Photobiol 1998, 68, 561

9. Ravanat, I; Cade, J.; Araki, K.; Toma, H. E; Medeiros, M. H. G.; Mascio, P. D. Photochent. Photobiol 1998,68, 698.

10. Gulaev, A. B.: Leontis, N. B. Biochem. $1999,38,15425$

11. Bold, B.; Barkhuu, B.; Lee, W; Shim, Y. K. Bull Konem Chem. Soc. 2008. 29. 237

12. Barkhuu, B. Develontent and Activity Tests of New Cationic Chlorins for Photothanic Concer Therapy, Thesis for Ph. D; Inje University, Korea, 2007

13. (a) Ghosh, A. In The Ponphyin Hondbook, Kardish, K. M: Smith, K. M.: Guilard, R., Eds, Academic Press: New York, 2000: Vol. 7. p l. (b) Shelnutt. J. A. In The Porphnin Handbook: Kardish, K. M; Smith, K. M; Guilard, R., Eds.; Academic Press: New York, 2000: Vol. 7, p l67. (c) Pandey, R. K.: Zheng. G. In The Porphin in Hondbook, Kardish, K. M.; Smith, K. M.; Guilard, R. Eds.: Academic Press: New York. 2000: Vol. 6. p 158

14. (a) Takenchi, T:; Gray, H. B.: Goddard III, W. A. J. .1m. Chem. Soc, 1994, 116, 9730 . (b) Wang, Z.; Day, P. N.; Pachter, R. J. Chem. Phys 1998, 108, 2504

15. Park, S. H.; Kim, S. J.; Kim, J. D.; Park, S.; Huh, D. S.; Shim, Y. K. Choe, S. I. Bull. Korean Chem. Soc. 2008, 29, 1141

16. Frisch, M. J.: Trucks, G. W.: Schlegel, H. B.: Gill, P. M. W: Johnson, B. G:; Robb, M. A; Cheeseman, J. R.; Keith, T:; Peterson, G. A.; Montgometry, J. A:; Raghavacari, K: AlLaham, M. A.; Zakrzewski, V. G.; Ortiz, T. V.; Foresman, T. B.; Cioslowski, J.: Stetanov, B. B.: Nanayakkara, A.: Challacombe, M.: Peng, C. J.: Ayala, P. Y.: Chen, W; Wong, M. W.: Andres, J. L.; Replogle, E. S.; Gomperts, R.; Martin, R. L.; Fox, D. L.; Binkley, I. S.: Detrees, D. I.: Baker, J.; Stewart, J. P.: Head-Gordon, M: Gonzalez, C. Pople .T. A. Gaussian, Inc.: Wallingtord, CT, 2005.

17. Goutenman, M. J. Hol. Spectrose. 1961, 6, 138.

18. Shelnutt, J. A.; Song, X. Z: Ma, J. G.; Jia, S. L.; Jentzen, W; Medtorth, C I. Chent Soc. Rev 1998, 27,31.

19. Jentzen. W: Ma. T. G.: Shelnutt. T. A. Biophus. J. 1998. 74. 753

20. Fischer, M.; Templeton, D.; Zalkin, A.; Calvin, M. J. Am. Chem. Soc. 1972, 94, 3613

21. Zhao, Y:; Truhlar, D. Acc. Chem. Res. 2008, $11,157$. 